\title{
Evaluation of the chemical composition of dry dogfoods commercialized in Chile used for growing dogs
}

\author{
[Avaliação da composição química de rações comerciais no Chile, usadas para filhotes]

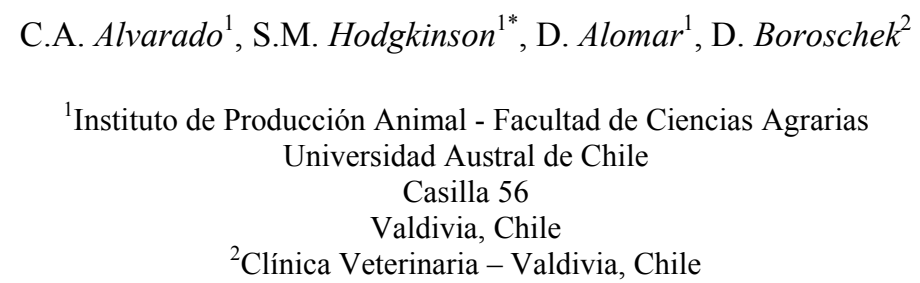

ABSTRACT

The nutritional quality of dry dogfood commercialized in Chile for growing dogs was studied. Samples from at least three different batches of 26 dogfood brands were mixed. The resultant samples $(n=26)$ were chemically analyzed to determine their concentrations of dry matter (DM), gross energy, fiber, ash, crude protein, essential amino acids, total fat, linoleic acid and minerals. The metabolizable energy (ME) content of each sample was estimated using modified atwater factors. The results from the chemical analyses were compared with the nutrient profiles published by the American Association of Feed Control Officials (AAFCO). Dogfoods that were found to contain an estimated ME of over 4,000kcal $/ \mathrm{kg}$ DM were corrected for their high energy density before comparison. All of the dogfoods contained adequate levels of protein, total fat, linoleic acid, iron, copper, manganese and selenium. The concentration of tryptophan was adequate in $92.3 \%$ of the samples. All of the other essential amino acids were present in adequate quantities. However, the situation was different for many of the minerals. Only $92.3 \%$ of the dogfoods contained an adequate $\mathrm{Ca}: \mathrm{P}$ ratio. A total of $96.2 \%$ of the dogfoods contained an adequate level of $\mathrm{Ca}, 96.2 \%$ for $\mathrm{P}, 96.2 \%$ for $\mathrm{Mg}, 92.3 \%$ for $\mathrm{I}, 88.5 \%$ for $\mathrm{Cl}, 80.8 \%$ for $\mathrm{Na}, 80.8 \%$ for $\mathrm{Zn}$ and only $34.6 \%$ were adequate for K content. Overall, only $23 \%$ of the dogfoods evaluated in this study fulfilled all of the requirements established by the AAFCO in terms of their content of crude protein, amino acids, total fat, linoleic acid, and minerals. It appears that the majority of the dogfoods evaluated in this study $(77 \%)$ would not satisfy all nutritional requirements of the growing dog.

Keywords: dog, dogfood, nutrition value

\section{RESUMO}

Determinou-se a qualidade nutricional de 26 rações para filhotes caninos comercializadas no Chile. As rações foram analisadas quimicamente e comparadas com as recomendações da American Association of Food Control Officials (AAFCO). Para as análises, utilizou-se uma amostra de cada ração, composta de pelo menos três lotes diferentes. Para cada amostra, foram determinados os conteúdos de matéria seca (MS), fibra, proteína bruta, aminoácidos essenciais, gordura, ácido linoléico e minerais. A energia metabolizável foi determinada mediante os fatores de conversão de Atwater e corrigida por sua densidade quando ultrapassava $4000 \mathrm{kcal} / \mathrm{kgMS}$. Todas as rações apresentaram conteúdos adequados de proteína, gordura, ácido linoléico, ferro, cobre, manganês e selênio. A concentração de triptofano foi adequada em 92,3\% das rações, e a dos demais aminoácidos essenciais foi maior que a mínima recomendada. As maiores irregularidades foram encontradas no conteúdo de minerais, 92,3\% das rações apresentaram uma adequada relação Ca:P. Foram observados níveis adequados de Ca, $P$ e $\mathrm{Mg} \mathrm{em}$

Recebido em 19 de abril de 2006

Aceito em 17 de dezembro de 2007

*Corresponding author (autor para correspondência)

Email: shodgkin@uach.cl

Financial support: Chilean Comisión Nacional de Investigación, Científica y Tecnológica - Project FONDECYT 1020912. 
96,2\% das rações, de I em 92,3\%, de Cl em 88,5\%, de Na e Zn em 80,8\% e de K em 34,6\%. Em relação às concentrações de proteína, aminoácidos, gordura, ácido linoléico e minerais, somente $23 \%$ das rações apresentavam todas as especificações recomendadas pela AAFCO. A maioria das rações analisadas, (77\%) apresentavam concentrações de nutrientes inferiores ao requerimento de filhotes caninos.

Palavras-chaves: cão, ração, valor nutricional

\section{INTRODUCTION}

The commercial petfood industry was initiated in London in 1860 by James Pratt, who sold dog biscuits. The enterprise was highly successful in England, so he began to sell them in the United States of America. Other companies have been selling petfoods since 1910 (Case et al., 2000).

In 2000 , the petfood industry registered worldwide sales of US\$27,000 million, with an annual growth between four and seven percent (Corbin, 2000). In Chile the sales in 2002 registered over US\$140 million, with an annual growth of $20 \%$ being reported (Sierra, 2003).

In spite of this growth, in Chile and other countries in South America, there is almost no information regarding the nutritional quality of the products marketed as "complete and balanced" dogfoods, with the result that consumers have no certainty that such products will satisfy all of the nutritional requirements of the dog. In Chile, standards for dogfoods have been developed (NCh2546), which establish the nutritional profiles that the industries that produce and commercialize these products must follow. There are, however, no inspection processes established to ensure that the industries do in fact follow these standards. The Chilean Standard states that foods commercialized for dogs and cats must follow the current quality standards established by the Association of American Feed Control Officials (AAFCO). The AAFCO was set up in the United States of America, with their primary functions including the publication of standards to regulate the ingredients utilized in animal foods, the quality of such foods, their labeling and assay protocols. These standards also establish the conditions that a food must fulfill to be labeled as "complete and balanced" (Official..., 2002).

The AAFCO (Official..., 2002) establishes two alternatives to verify that a dogfood is complete and balanced. The first alternative involves feeding trials following an established protocol.
The second alternative requires that the foods be formulated to fulfill a specific nutritional profile. The values given in this nutritional profile differ from the values established by the National Research Council (Nutrient..., 1985), which were determined using purified ingredients, with a high nutrient availability. Commercial dogfoods are, however, formulated using predominantly by-products (Murray et al., 1997) which have a much lower availability to the animal, a factor which has been taken into consideration in the development of the AAFCO nutrient profiles.

The objective of the present study was to determine the contents of crude protein (CP), essential amino acids, total fat (TF), linoleic acid and minerals in commercial dry dogfoods formulated for growing dogs which are available on the Chilean market, and compare these values with those established in the AAFCO nutrient profiles.

\section{MATERIALS AND METHODS}

To select the brands to be evaluated, a list was compiled containing all dry dogfood brands commercially available on the Chilean market in December, 2002. Of the 43 brands on the list, 26 were chosen, firstly selecting those commercialized in supermarkets, assuming a greater volume of sales of these brands. Other brands were then chosen at random, until a total of 26 had been included. Of these 26 brands, 12 (46\%) had been manufactured in Chile. Of the remaining 14, five were manufactured in the United States of America, five were manufactured in Argentina, two in Canada, one in Brazil and one in France. The samples of these dogfoods were bought from supermarkets, veterinary clinics and specialized stores between December 2002 and May 2003. The brands that were evaluated are listed in Table 1. The information on the packaging regarding minimum and maximum nutrient contents was 
recorded and subsequently compared with the analysed results.

Table 1. Commercial brands of dogfoods included in the study

\begin{tabular}{lll}
\hline & \multicolumn{3}{c}{ Brands } \\
\hline 5 Continentes & Champion & Max Filhote \\
Acomer & Dog Chow & Pedigree \\
Alpo & Dog Food & Precept \\
Amino Dog & Dogui & Pro Nature \\
Bil-jac & Doko & Pro Plan \\
Bobican & Eukanuba & Royal Canin \\
Cachupin & First Choice & Sabrokan \\
Canito & Hill's & Star Pro \\
& Science Diet & \\
Cannes & Masterdog & \\
\hline
\end{tabular}

For each brand in evaluation, a $300 \mathrm{~g}$ sample was obtained from at least three different batches. The batches were identified by differences in fabrication or expiry dates on packaging or by batch number. The samples were then ground in a mill with a $1 \mathrm{~mm}$ sieve and homogenized.

Each dogfood sample was chemically analyzed as detailed below, with all chemical analyses carried out in duplicate. The CP content of the samples was determined via the Kjeldahl method ( $\mathrm{N} x$ 6.25; Bateman, 1970). Amino acids were determined following hydrolysis of duplicate samples $(5-7 \mathrm{mg})$ in $1 \mathrm{ml}$ of $6 \mathrm{~mol} / 1$ glass-distilled $\mathrm{HCl}$ containing $0.1 \%$ phenol in glass tubes sealed under vacuum, for 24 hours at $110 \pm 2^{\circ} \mathrm{C}$. Amino acid concentrations were measured using a waters ion exchange HPLC system calibrated against a reference amino acid mixture of known concentration. The peaks of the chromatograms were integrated using the dedicated software Maxima $820^{1}$ which identifies the amino acids by retention time against a reference amino acid mixture. Norleucine and lysozyme were used as internal and external standards, respectively, and the weight of each amino acid was calculated using free amino acid molecular weights. No corrections were made for losses of amino acids during hydrolysis. Cysteine and methionine are destroyed during acid hydrolysis, so were determined by oxidation of duplicate samples (3-4mg) with $1 \mathrm{ml}$ of performic acid ( 1 part $30 \% \mathrm{H}_{2} \mathrm{O}_{2}$ to 9 parts $88 \%$ formic acid) for 16 hours at $0^{\circ} \mathrm{C}$. The samples were then neutralized with $0.15 \mathrm{ml}$ of $50 \%$ (w/w) $\mathrm{HBr}$

${ }^{1}$ Waters, Millipore, Milford, MA, USA. prior to acid hydrolysis. Tryptophan, which is also destroyed during acid hydrolysis, was determined via the method described by the Association of Official Analytical Chemists (AOAC; Official..., 1995).

The TF content of the samples was determined via the acid hydrolysis method recommended by AOAC for extruded petfoods (method 954.02; Official..., 1995). Linoleic acid was determined by gas chromatography (Cantellops et al., 1999). The contents of the minerals I and $\mathrm{Cl}$ were determined according to the method described by Fecher et al. (1998). The extraction was carried out with tetramethylammonium hydroxide (TMAH) and determination with inductively coupled plasmamass spectrometry (ICP-MS). The Se content of the samples was determined by atomic absorption spectrophotometry (spectrophotometer Varian VGA77 with hydride generation), with a wavelength of $196 \mathrm{~nm}$, following digestion of the sample with a mixture of $\mathrm{H}_{2} \mathrm{O}_{2}, \mathrm{HNO}_{3}$ and $\mathrm{H}_{2} \mathrm{SO}_{4}$ followed by $\mathrm{HCl}$ (Brodie, 1985; Brimmer et al., 1987). The contents of $\mathrm{Ca}, \mathrm{K}, \mathrm{Na}, \mathrm{Mg}, \mathrm{Fe}, \mathrm{Cu}, \mathrm{Mn}$ and $\mathrm{Zn}$ were determined using atomic absorption spectrophotometry, using a UNICAM UV 6-420 Supersipper spectrophotometer, following wet digestion with nitric and perchloric acids (Official..., 1995). The $\mathrm{P}$ content of the samples was determined using the molibdovanadate method (colorometry) described by AOAC (Official..., 1970).

The gross energy of the samples was determined using oxygen bomb calorimetry (Bateman, 1970). Dry matter (DM), crude fiber (acid digestion) and ash (calcination at $550^{\circ} \mathrm{C}$ ) contents were all determined following the methods described by AOAC (Official..., 1995). The nitrogen-free extract (NFE) content of the samples was calculated by subtracting the contents of $\mathrm{CP}, \mathrm{TF}$, crude fiber and ash from the total DM content.

The metabolizable energy (ME) content of the dogfood samples was calculated using Modified Atwater Factors using the following formula (Official..., 2002):

$\operatorname{ME}\left(\mathrm{kcal} \mathrm{kg}^{-1}\right)=10[(3.5 \times \mathrm{CP})+(8.5 \mathrm{x} \mathrm{TF})+(3.5$ $x$ NFE)], where CP, TF and NFE were as $\%$ of DM.

In order to proceed with the nutrient evaluations, the results obtained from chemical analyses and 
calculations were compared with the nutrient profiles recommended by AAFCO (Official..., 2002) for growing dogs. When necessary (dogfood with more than 4,000kcal ME kg ${ }^{-1} \mathrm{DM}$ ) the appropriate corrections for the energy content (Official..., 2002) was made prior to the nutritional evaluation of the foods.

The results obtained from the chemical analyses were also compared with the guaranteed nutrient contents published on the packaging of each dogfood.

\section{RESULTS}

All dogfood packaging contained guaranteed nutrient contents, including maximum DM and crude fiber content and minimum content of $\mathrm{CP}$ and TF, as established in the Chilean Standard (Alimentos..., 2001). When the guaranteed nutrient contents were compared with the nutrient contents determined by chemical analyses, all of the dogfoods were found to contain levels of DM and crude fiber lower than the maximum levels guaranteed. However, two of the 26 dogfoods analyzed contained lower levels of $\mathrm{CP}$ than the guaranteed minimum contents, and one dogfood contained a level of $\mathrm{TF}$ that was lower than the minimum level guaranteed on the packaging.

The range, mean and SEM for the results of the chemical analyses, following correction for high energy density when necessary, are presented in Tables 2 and 3. There was a very large variation in nutrient concentrations of dogfoods with a difference in the minimum and maximum values of up to six times. Moreover, one dogfood contained $33.4 \mathrm{mg} \mathrm{kg}^{-1}$ of iodine, which was considered a very high value, meanwhile other dogfoods contained levels of iodine in the range 0.77 to $5.75 \mathrm{mg} \mathrm{kg}^{-1}$. As can be observed in Table 2, all dogfoods contained more than 3,500kcal ME $\mathrm{kg}^{-1} \mathrm{DM}$, the minimum level recommended in diets for growing dogs (Official..., 2002).

Table 2. Range, mean and standard error of the mean (SEM) of the chemical composition of commercial foods for growing dogs $(n=26 \text {, dry matter basis })^{1}$ commercialized in Chile

\begin{tabular}{lccc}
\hline Nutrient & Range & Mean & SEM \\
\hline Dry matter (\%) & $89.7-94.7$ & 92.5 & 0.18 \\
Crude fiber (\%) & $0.6-3.3$ & 1.8 & 0.12 \\
Nitrogen-free extract (\%) & $32.4-51.8$ & 44.8 & 0.92 \\
Ash (\%) & $5.8-9.9$ & 7.5 & 0.19 \\
Total energy (kcal/kg) & $4950-5520$ & 5090 & 37.0 \\
Metabolizable energy (kcal/kg) & $3729-4385$ & 3962 & 35.6 \\
Crude protein (\%) & $23.4-33.2$ & 28.2 & 0.61 \\
Arginine (\%) & $1.29-2.09$ & 1.67 & 0.043 \\
Histidine (\%) & $0.49-0.83$ & 0.67 & 0.017 \\
Isoleucine (\%) & $0.74-1.29$ & 0.99 & 0.026 \\
Leucine (\%) & $1.61-3.27$ & 2.36 & 0.084 \\
Lysine (\%) & $0.86-1.65$ & 1.27 & 0.041 \\
Methionine-Cisteine (\%) & $0.77-1.32$ & 1.00 & 0.027 \\
Phenylalanine-Tyrosine (\%) & $1.59-2.71$ & 2.05 & 0.058 \\
Threonine (\%) & $0.70-1.14$ & 0.93 & 0.022 \\
Tryptophan (\%) & $0.17-0.31$ & 0.25 & 0.008 \\
Valine (\%) & $0.97-1.71$ & 1.31 & 0.033 \\
Total fat (\%) & $10.4-18.4$ & 14.6 & 0.41 \\
Linoleic acid (\%) & $1.4-5.7$ & 3.3 & 0.20 \\
\hline
\end{tabular}

${ }^{\mathrm{T}}$ The levels of the nutrients (except for energy and dry matter) in dogfood that contained $>4,000 \mathrm{kcal} \mathrm{ME} / \mathrm{kg}$ DM have been corrected as described in the text.

${ }^{2}$ Metabolizable energy calculated from determined contents of crude protein, total fat and nitrogen-free extract, using Modified Atwater Factors (see text for details). 
Table 3. Range, mean and standard error of the mean (SEM) of the mineral contents of the dogfoods evaluated $(\mathrm{n}=26 \text {, dry matter basis })^{1}$

\begin{tabular}{lccc}
\hline Mineral & Range & Mean & SEM \\
\hline Calcium (\%) & $0.99-2.48$ & 1.57 & 0.092 \\
Phosphorus (\%) & $0.70-1.40$ & 1.04 & 0.033 \\
Calcium:phosphorus ratio & $0.95-2.35$ & 1.40 & 0.066 \\
Potassium (\%) & $0.38-0.84$ & 0.55 & 0.024 \\
Sodium (\%) & $0.20-0.61$ & 0.37 & 0.019 \\
Chloride (\%) & $0.26-1.29$ & 0.68 & 0.041 \\
Magnesium (\%) & $0.07-0.36$ & 0.16 & 0.015 \\
Iron (mg $/ \mathrm{kg})$ & $197.2-700.6$ & 368.2 & 23.86 \\
Copper (mg/kg) & $8.9-54.0$ & 32.3 & 2.13 \\
Manganese (mg/kg) & $18.8-137.8$ & 59.3 & 6.27 \\
Zinc (mg/kg) & $74.5-317.0$ & 178.9 & 11.30 \\
Iodine (mg/kg) & $0.77-33.49$ & 4.15 & 1.202 \\
Selenium (mg/kg) & $0.24-1.31$ & 0.57 & 0.053 \\
\hline
\end{tabular}

${ }^{\mathrm{T}}$ The levels of the nutrients (except for energy and dry matter) in dogfood that contained $>4,000 \mathrm{kcal} \mathrm{ME} / \mathrm{kgDM}$ have been corrected as described in the text.

The nutrient contents recommended for dogfoods for growing dogs in the AAFCO Dogfood Nutrient Profiles (Official..., 2002) and the percentage of the analyzed dogfoods that fulfilled these nutrient contents in terms of $\mathrm{CP}$, amino acids, $\mathrm{TF}$, linoleic acid and minerals are presented in Tables 4 and 5. Only $92 \%$ ( 24 of the 26 ) of the dogfoods contained a level of tryptophan that was greater than the minimum recommended by the AAFCO. All dogfoods contained sufficient amounts of the remaining amino acids. All of the dogfoods evaluated contained levels of protein, lipids, linoleic acid, iron, copper, manganese and selenium that were greater than the minimum concentrations and lower than the maximum concentrations (for the nutrients where a maximum concentration has been established) recommended by the AAFCO. A total of $96.2 \%$ (25 of the 26 dogfoods for each nutrient) fulfilled the maximum values established by the AAFCO in terms of the calcium to phosphorus ratio and the concentrations of calcium, phosphorus and magnesium. Moreover, 92.3\% (24 of 26 dogfoods) satisfied the minimum concentrations of iodine recommended by AAFCO, $88.5 \%$ (23 of 26) for chloride, $80.8 \%$ (21 of 26) for sodium and zinc and only $34.9 \%$ ( 9 of 26 ) for potassium.

Table 4. Minimum concentrations of protein, essential amino acids, total fat and linoleic acid recommended $^{1}$ and percentage of the dogfoods that satisfied these minimum amounts (dry matter basis)

\begin{tabular}{lcc}
\hline Nutrient & $\begin{array}{c}\text { Recommendation } \\
\text { (minimum \%) }\end{array}$ & $\begin{array}{c}\text { Dogfoods that satisfied the } \\
\text { recommendation }\end{array}$ \\
\hline Protein & 22.0 & 100.00 \\
Arginine & 0.62 & 100.00 \\
Histidine & 0.22 & 100.00 \\
Isoleucine & 0.45 & 100.00 \\
Leucine & 0.72 & 100.00 \\
Lysine & 0.77 & 100.00 \\
Methionine-Cisteine & 0.53 & 100.00 \\
Phenylalanine-Tyrosine & 0.89 & 100.00 \\
Threonine & 0.58 & 100.00 \\
Tryptophan & 0.20 & 92.31 \\
Valine & 0.48 & 100.00 \\
Total fat & 8 & 100.00 \\
Linoleic acid & 1 & 100.00 \\
\hline
\end{tabular}

${ }^{\mathrm{T}}$ Official... (2000).

${ }^{2}$ Presumes an energy density of $3,500 \mathrm{kcal} \mathrm{ME} / \mathrm{kgDM}$.

${ }^{3}$ The levels of nutrients in dogfoods that contained $>4000 \mathrm{kcal} \mathrm{ME} / \mathrm{kgDM}$ have been corrected as described in the text. 
Table 5. Minimum and maximum concentration of minerals recommended ${ }^{1}$ and percentage of the dogfoods that fulfilled these concentrations (dry matter basis)

\begin{tabular}{lcccc}
\hline \multirow{2}{*}{ Mineral } & \multicolumn{2}{c}{ Recommendation $^{1}$} & $\begin{array}{c}\text { Dogfoods that satisfied the } \\
\text { recommendation } \\
\text { (\%) }\end{array}$ \\
\cline { 2 - 5 } & Minimum & Maximum & Minimum & Maximum \\
\hline Calcium (\%) & 1 & 2.5 & 96.15 & 100.00 \\
Phosphorus (\%) & 0.8 & 1.6 & 96.15 & 100.00 \\
Calcium:phosphorus ratio & 1.0 & 2.0 & 96.15 & 96.15 \\
Potassium (\%) & 0.6 & - & 34.62 & - \\
Sodium (\%) & 0.3 & - & 80.77 & - \\
Chloride (\%) & 0.45 & - & 88.46 & - \\
Magnesium (\%) & 0.04 & 0.3 & 100.00 & 96.15 \\
Iron (mg/kg) & 80 & 3,000 & 100.00 & 100.00 \\
Copper (mg/kg) & 7.3 & 250 & 100.00 & 100.00 \\
Manganese (mg/kg) & 5 & - & 100.00 & - \\
Zinc (mg/kg) & 120 & 1,000 & 80.77 & 100.00 \\
Iodine (mg/kg) & 1.5 & 50 & 92.31 & 100.00 \\
Selenium (mg/kg) & 0.11 & 2 & 100.00 & 100.00 \\
\hline
\end{tabular}

${ }^{\top}$ Official... (2002).

${ }^{2}$ Presumes an energy density of $3,500 \mathrm{kcal} \mathrm{ME} / \mathrm{kgDM}$.

${ }^{3}$ The levels of nutrients in dogfoods that were found to contain more than $4000 \mathrm{kcal} \mathrm{ME} / \mathrm{kgDM}$ have been corrected as described in the text.

As shown in Figure 1, only 23\% (6 of the 26 dogfoods) of the dogfoods evaluated in this study fulfilled all AAFCO nutrient recommendations in terms of the macronutrients and minerals.

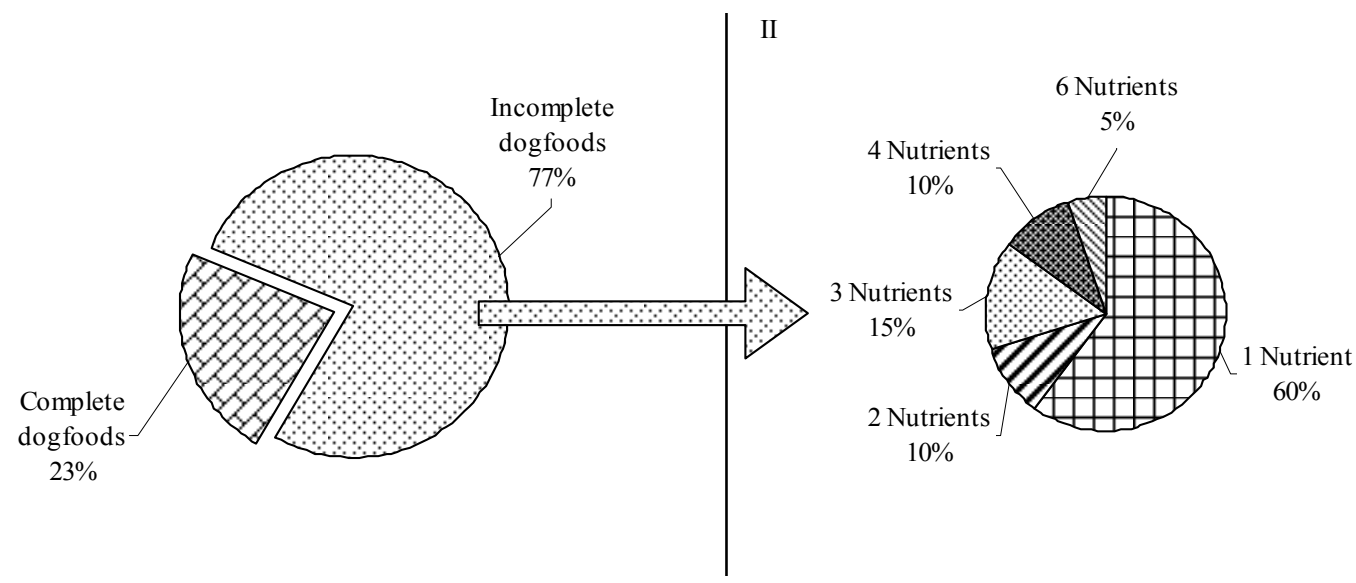

Figure 1. (I) Percentage of the dogfoods that satisfied the AAFCO profile (Official..., 2002); (II) distribution of those that did not, according to the number of nutrients present in incorrect amounts. 


\section{DISCUSSION}

The AAFCO has been recognized by many sources as the world-wide authority on animal feeds (Case et al., 2000; Corbin, 2000; Hendriks and Moughan, 2000; Thatcher et al., 2000), and their recommendations and standards have been widely used for scientific studies (Steiff et al., 2002) and legal standards in some countries including Chile (Alimentos..., 2001). All of the analyses carried out as part of the present study were conducted in the manner recommended by the AAFCO (Official..., 2002) as one of the alternatives to determine whether dogfoods formulated for growing dogs are complete and balanced. The vitamin contents were not evaluated in the present study due to budget constraints.

Analysis of the information contained on the packaging of the dogfoods showed that all presented basic nutritional composition data including DM, CP, TF and crude fiber contents, as is required by the Chilean Standard (Alimentos..., 2001). Regarding other essential nutrients, only 14 of the dogfoods evaluated presented additional information, and only limited information was presented, mainly regarding the contents of macrominerals $(\mathrm{Ca}$ and $\mathrm{P})$. In general there was a good agreement between the information presented on the packaging and the results from the present study, except in the case of three dogfoods, which contained lower concentrations of crude protein or total fat than that guaranteed on the packaging.

With respect to the chemical analyses, firstly all of the dogfoods had relatively high DM contents, with an average of $92.5 \%$, with all dogfoods fitting within the "dry dogfood" category (DM contents between 89 and 97\%; Crane et al., 2000). The very large variation between dogfoods with regard to the nutrients contents is likely to be due to the high incorporation of by-products in these diets, as evidenced by the ingredient lists on the packaging. Dogfoods formulated using by-products have been shown to exhibit marked variation in nutrient content (Murray et al., 1997).

The ME contents of the dogfoods were estimated using Modified Atwater Factors, a methodology that is accepted by the AAFCO to give a good estimation of the ME content. This information was subsequently used to correct the nutrient contents in dogfoods that were found to contain more than $4,000 \mathrm{kcal} / \mathrm{kg} \mathrm{DM}$ of ME, proportionally decreasing the nutrient content. All of the dogfoods were found to have ME contents over $3,500 \mathrm{kcal} / \mathrm{kg}$ DM. Concentrations of ME lower than $3,500 \mathrm{kcal} / \mathrm{kg} \mathrm{DM}$ are not recommended by AAFCO (Official.., 2002) for growing dogs, as the physical limitations of the digestive tract of young animals will not allow a sufficient ME intake. However, ten of the 26 dogfoods contained more than $4,000 \mathrm{kcal} / \mathrm{kg} \mathrm{DM}$ of $\mathrm{ME}$, thus requiring a correction of their nutrient contents as discussed above.

When the results of the chemical analyses were compared with the recommendations of the AAFCO (Official..., 2002), almost all of the dogfoods fulfilled the minimum protein and amino acid contents recommended, except for two dogfoods that did not contain the minimum amount of tryptophan. Amino acids (and proteins in general) are required for numerous biological processes, including growth, formation and repair of tissues and the synthesis of blood and immunological proteins. The lack of dietary essential amino acids is compensated for via tissue protein catabolism, resulting in low growth rates, lethargy, lowered immune function and decreased milk production in lactating animals (Dzanis, 1997).

All of the dogfoods were found to contain adequate levels of fat and linoleic acid according to the values of the AAFCO (Official..., 2002).

In terms of the mineral contents of the evaluated dogfoods, two situations were found. For some minerals all of the dogfoods contained adequate amounts, according to the AAFCO (Official..., 2002). This was the case for iron, copper, manganese and selenium. However, for the remaining minerals, at least some of the dogfoods did not contain adequate amounts (Table 5). The most common deficiency was found for potassium, for which only $34.6 \%$ of the dogfoods contained adequate amounts (more than $0.6 \%$ on a DM basis). A similar situation was found in a study conducted in Mexico, where 31 commercial dry dogfoods were evaluated, of which 12 were formulated for growing dogs (of these 12 dogfoods, 6 were also including in the present study) and in which $50.1 \%$ of the 31 dogfoods (and $58.3 \%$ of the twelve dogfoods for growing dogs) were found to have deficient levels of this mineral (Alimento..., 2002). 
The potential effects on the health and well-being for dogs that receive dogfoods containing too low levels of potassium include low growth rates, weakness, and sometimes serious paralysis problems (McDonald et al., 1995), as well as heart muscle lesions (Nutrient..., 1985; Gross et al., 2000).

Sodium deficiency (which occurred in five of the 26 dogfoods evaluated) or chloride deficiency (as in three of the 26 dogfoods) can result in fatigue, exhaustion, incapability to maintain an adequate water balance, decreased water intake, growth retardation, dry skin and loss of hair (Nutrient..., 1985). Dogs that receive an inadequate amount of zinc (as with five of the 26 dogfoods evaluated), can show retarded growth rates, anorexia, parakeratosis, hyperkeritinization, coarse hair coat, alopecia, testicular atrophy, conjunctivitis, immune system dysfunction, and the presence of skin lesions (McDonald et al., 1995; Case et al., 2000).

Overall, when the deficiencies and excesses of all of the nutrients that were analyzed in the present study were considered, only $23 \%$ of the dogfoods evaluated could be considered to be nutritionally complete (Fig. 1), from the point of view of protein, essential amino acids, fat, linoleic acid and the minerals. It should be noted that the majority of the nutrients that were present in inadequate amounts in the dogfoods were minerals. Minerals are required in low quantities and when included in the diet remain stable over time, and can be included in a well-formulated mineral premix. Therefore, it is important that the dogfood manufacturers take the results of the present study as an important alert, and use them as an orientation to improve their formulation.

Finally, it should be noted that the chemical analysis of commercial dogfoods should only be considered as the first stage in the determination of their nutritional quality. In the future it will be necessary to consider the bioavailability of some of these nutrients, especially in the case of protein, amino acids and energy, through digestibility trials.

\section{REFERENCES}

ALIMENTO para mascotas. Rev. Consum., v.307, p.1-8, 2002.

ALIMENTOS completos para perros y gatos. Santiago: Instituto Nacional de Normalización,
2001. 18p. (Norma Chilena Oficial 2546.Of2001).

BATEMAN, J. Nutrición animal: manual de métodos analíticos. México, DF: Herrera Hermanos, Sucesores, 1970. 468p.

BRIMMER, S.; FAWCETT, W.; KULHAVY, K. Quantitative reduction of selenate ion to selenite in aqueous samples. Anal. Chem., v.59, p.1470-1471, 1987.

BRODIE, K. Analysis of plants materials by vapor generation AA. Victoria, Australia: Varian, 1985. 4p. (Varian Instrument at Work, n.AA $50)$.

CANTELLOPS, D.; REID, A.; EINTENMILLER, R. et al. Determination of lipids in infants formula powder by direct extraction methylation of lipids and fatty acid methyl esters (FAME) analysis by gas chromatography. J. Assoc. Off. Anal. Chem. Int., v.82, p.1128-1139, 1999.

CASE, L.; CAREY, D.; HIRAKAWA, D. et al. Canine and feline nutrition: a resource for companion animal professionals. 2.ed. St. Louis, Missouri: Mosby , 2000. 592p.

CORBIN, J. Pet foods and feeding. Feedstuffs, v.72, p.72-76, 2000.

CRANE, S.; GRIFFIN, R.; MESSENT, P. Introduction to commercial pet foods. In: HAND, M.; THATCHER, C.; REMILLARD, R. et al. (Eds.). Small animal clinical nutrition. 4.ed. Kansas: Mark Morris Institute, 2000. p.111-126.

DZANIS, D. Disorders of nutritional deficiency. In: MORGAN, R. (Ed.). Handbook of small animal practice. 3.ed. Philadelphia: Saunders, 1997. p.1227-1236.

FECHER, P.; GOLDMANN, I.; NAGENGAST, A. Determination of iodine in food samples by inductively coupled plasma-mass spectrometry after alkaline extraction. J. Anal. At. Spectrom., v.13, p.977-982, 1998.

GROSS, K.; WEDEKIND, K.; COWELL, C. et al. Nutrients. In: HAND, M.; THATCHER, C.; REMILLARD, R. et al. (Eds.). Small animal clinical nutrition. 4.ed. Kansas: Mark Morris Institute, 2000. p.20-110.

HENDRIKS, W.H.; MOUGHAN, P.J. Advances in feed evaluation for companion animals. In: 
MOUGHAN, P.J.; VERSTEGEN, M.W.A.; VISSER-REYNEVELD, M.I. (Eds.). Feed evaluation, principles and practice. Wageningen: Wageningen Press, 2000. p.269-285.

MACDONALD, P.; EDWARDS, R.A.; GREENHALGH, J.F.D. et al. Animal Nutrition. 5.ed. New York: Longman Scientific and Technical, 1995. 607p.

MURRAY, S.; PATIL, A.; FAHEY, G. et al. Raw and rendered animal by-products as ingredients in dog diets. J. Anim. Sci., v.75, p.2497-2505, 1997.

NUTRIENT requirements of dogs. Washington, DC: National Academy, 1985. 79p.

OFFICIAL publication. Atlanta: Association of American Feed Control Official, 2002. 464p.

OFFICIAL methods of analysis. 16.ed. Washington, DC: AOAC, 1995.
OFFICIAL methods of analysis. 11.ed. Washington, DC: AOAC, 1970.

SIERRA, A. Chilenos gastan \$21960 anual en comida de perros y gatos. Mercurio, Santiago, Chile. 2003. p.B3. 26 mayo

STEIFF, E.; ZWISCHENBERGER, B.; BUTTERWICK, R. et al. A comparison of the nutritional adequacy of home-prepared and commercial diets for dogs. J. Nutr., v.130, p.1698S-1700S, 2002.

THATCHER, C.; HAND, M.; REMILLARD, R. Small animal clinical nutrition: an iterative process. In: HAND, M.; THATCHER, C.; REMILLARD, R. et al. (Eds.). Small animal clinical nutrition. 4.ed. Kansas: Mark Morris Institute, 2000. p.1-19. 